\title{
Patient-public engagement strategies for health system improvement in sub-Saharan Africa: a systematic scoping review
}

Samuel Egyakwa Ankomah ${ }^{1}$, Adam Fusheini ${ }^{1,2^{*}}$, Christy Ballard ${ }^{3}$, Emmanuel Kumah ${ }^{4}$, Gagan Gurung ${ }^{5}$ and Sarah Derrett ${ }^{\top}$

\begin{abstract}
Background: Actively involving patients and communities in health decisions can improve both peoples' health and the health system. One key strategy is Patient-Public Engagement (PPE). This scoping review aims to identify and describe PPE research in Sub-Saharan Africa; systematically map research to theories of PPE; and identify knowledge gaps to inform future research and PPE development.

Methods: The review followed guidelines for conducting and reporting scoping reviews. A systematic search of peer-reviewed English language literature published between January 1999 and December 2019 was conducted on Scopus, Medline (Ovid), CINAHL and Embase databases. Independent full text screening by three reviewers followed title and abstract screening. Using a thematic framework synthesis, eligible studies were mapped onto an engagement continuum and health system level matrix to assess the current focus of PPE in Sub-Saharan Africa.

Results: Initially 1948 articles were identified, but 18 from 10 Sub-Saharan African countries were eligible for the final synthesis. Five PPE strategies implemented were: 1) traditional leadership support, 2) community advisory boards, 3) community education and sensitisation, 4) community health volunteers/workers, and 5) embedding PPE within existing community structures. PPE initiatives were located at either the 'involvement' or 'consultation' stages of the engagement continuum, rather than higher-level engagement. Most PPE studies were at the 'service design' level of the health system or were focused on engagement in health research. No identified studies reported investigating PPE at the 'individual treatment' or 'macro policy/strategic' level.

Conclusion: This review has successfully identified and evaluated key PPE strategies and their focus on improving health systems in Sub-Saharan Africa. PPE in Sub-Saharan Africa was characterised by tokenism rather than participation. PPE implementation activities are currently concentrated at the 'service design' or health research levels. Investigation of PPE at all the health system levels is required, including prioritising patient/community preferences for health system improvement.
\end{abstract}

Keywords: Patient-public engagement, Community engagement, Social accountability, Health system improvement, Health interventions, Sub-Saharan Africa

\footnotetext{
* Correspondence: adam.fusheini@otago.ac.nz

${ }^{1}$ Department of Preventive and Social Medicine, University of Otago, PO Box

56, Dunedin 9054, New Zealand

${ }^{2}$ Center for Health Literacy and Rural Health Promotion, Accra, Ghana

Full list of author information is available at the end of the article
}

(c) The Author(s). 2021 Open Access This article is licensed under a Creative Commons Attribution 4.0 International License, which permits use, sharing, adaptation, distribution and reproduction in any medium or format, as long as you give appropriate credit to the original author(s) and the source, provide a link to the Creative Commons licence, and indicate if changes were made. The images or other third party material in this article are included in the article's Creative Commons licence, unless indicated otherwise in a credit line to the material. If material is not included in the article's Creative Commons licence and your intended use is not permitted by statutory regulation or exceeds the permitted use, you will need to obtain permission directly from the copyright holder. To view a copy of this licence, visit http://creativecommons.org/licenses/by/4.0/ The Creative Commons Public Domain Dedication waiver (http://creativecommons.org/publicdomain/zero/1.0/) applies to the data made available in this article, unless otherwise stated in a credit line to the data. 


\section{Introduction}

Despite implementing many health interventions to improve health and health systems in Sub-Saharan Africa, concerns remain about ongoing disappointing health outcomes. A key reason for this may be the inability of health interventions to adequately respond to the perceived needs and interests of the population [1]. A comprehensive review of the extent and nature of community participation and important facilitators and barriers in health systems research for LMICs has not yet focused on Sub-Saharan Africa [2]. Calls have been made for an increased emphasis on engaging communities when implementing health initiatives in SubSaharan Africa [3].

The Sub-Saharan Africa region contains less than $10 \%$ of the world's population yet it carries an estimated $24 \%$ of the global burden of diseases in both human and financial cost [4]. For instance, $60 \%$ of the world's burden of the HIV/AIDS epidemic is concentrated in Africa with greater majority found in Sub-Saharan Africa [5]. Additionally, other tropical diseases such as malaria, onchocerciasis, schistosomiasis, and lymphatic filariasis continue to adversely affect the region [6]. It is estimated that $90 \%$ of the $300-500$ million people infected with malaria worldwide each year live in Sub-Saharan Africa [7]. Although improvements have been reported [8], the WHO reports that 19 of 20 countries with the highest maternal mortality rates worldwide are in Sub-Saharan Africa [7].

There is, however, evidence that actively engaging people in planning and implementing major health programmes improves both health outcomes and the health system [9]. Patient-Public Engagement (PPE) has, therefore, been promoted as a key strategy to achieving this. Various PPE reviews conducted in other parts of the world have reported on PPE's positive effect on health system improvement [10-14]. A review conducted in the United Kingdom (UK) found engagement with layvolunteers and patients impactful, particularly when designing clinical trials or implementing community-based health programmes [14]. Similarly, another review conducted in Anglo-American contexts and other countries also recommended the need to identify key PPE strategies and situate them within the context of health system levels for effective health policy design [15].

PPE has been defined as the active engagement of citizens, users, carers and their representatives in the development of health care services and as partners in their own health care [16].

Engagement can include: identifying health strategies, setting the health care agenda, planning, selecting the implementation of major health initiatives, and involvement in accountability processes [17-20]. Engagement helps ensure health policies and/or programmes are responsive to the health needs of all groups within the community, particularly, women and children, elderly, adolescents, indigenous and ethnic groups [21]. The 1978 Alma-Ata Declaration on Primary Health Care further states that people have the right and duty to participate individually and collectively in the planning and implementation of health care [22]. Consequently, engagement as a basic human right offers a strategic route to addressing poor health outcomes [9].

Despite the demonstrated advantages of PPE for health, low levels of engagement have been found in Sub-Saharan Africa [23, 24]. Some studies in SubSaharan Africa have interventions to be inappropriate for communities, or tokenistic, which may partly account for low levels of engagement $[25,26]$. Literature on PPE initiatives in the region does not appear to have been synthesised to provide an understanding of how PPE initiatives have affected health outcomes, health care delivery, or the barriers and facilitators of effective PPE implementation [8, 27-29]. Other reviews of PPE initiatives have found very few PPE strategies have been implemented [30-32]. While these findings are useful, it is also necessary to synthesise and appraise the PPE strategies, particularly, in Sub-Saharan Africa, to describe the health system levels and engagement stages at which PPE is operating and to understand its overall effect on improving the health care system and outcomes.

To address these knowledge gaps, this scoping review aims to identify and synthesise published literature on PPE strategies implemented across Sub-Saharan Africa. Specifically, this paper describes how identified initiatives have impacted on health and health system improvement, and systematically maps identified PPE initiatives onto a framework comprising both health system levels and an engagement continuum.

\section{Methods}

We conducted a systematic scoping review of published peer-reviewed research articles published between 1999 and 2019 reporting PPE strategies aimed at improving health systems in Sub-Saharan Africa. The detailed scoping review protocol has been published [33]. Briefly, we followed Arksey and O'Malley's guidelines for conducting this scoping review [34-36]. We also reported results using the Preferred Reporting Items for Systematic Reviews and Meta-Analysis extension for scoping reviews (PRISMA-ScR) [37]. The scoping review questions, informed by the Population, Concept and Context (PCC) framework [37] were:

1. "What PPE strategies for improving health systems have been implemented in Sub-Saharan Africa and reported in peer-reviewed literature? 
2. What are the outcomes of these identified PPE strategies and strategies for health system improvement in Sub-Saharan Africa?

3. What are the current knowledge gaps about PPE in Sub-Saharan Africa?" [33] (p.4).

\section{Data analysis}

We employed thematic framework analysis to analyse the literature identified [38-40]. All studies were mapped onto an engagement continuum framework (Table 2; SEA, AF and SD) adapted from Bombard et.al, Gurung et.al, Ocloo and Matthews, Bate and Robert [12, 54-56] and applied in this study to understand whether engagement strategies have been implemented at the 'consultation', 'involvement' or 'partnership and shared leadership' stages. The settings in which these PPE strategies were implemented were also identified and mapped onto the framework. The mapping of the studies onto the framework was independently verified by two members of the research team (SD and AF).

\section{Results}

A total of 1948 articles were initially identified; 1933 through database searching, and 15 through handsearching of the reference lists of identified articles (Fig. 1). Following removal of duplicate records, the number reduced to 587. A further 548 papers were excluded following the title/abstract screening, leaving 39 papers for full text screening. After applying the inclusion and exclusion criteria, 21 articles were excluded (16 were not focused on PPE strategies, barriers or facilitators; 3 were not focused on sub-Saharan Africa; and 2 were discussion or editorial papers). Therefore, 18 articles were retained for final synthesis.

\section{Characteristics of the included studies}

The 18 eligible papers reported on 18 discrete studies undertaken in 10 Sub-Saharan African countries (Table 1). Most studies $(n=14)$ used qualitative methods $[1,3,28,29,31,41-43,46-51]$, one was quantitative [45], and three used mixed methods [44, 52, 53].

\section{Study findings}

The following major categories of PPE strategies implemented across Sub-Saharan Africa were identified: (1) traditional leadership support and collaboration; (2) community advisory boards; (3) community education and sensitisation; (4) community health volunteers/ workers; and (5) aligning and embedding PPE within existing community structures. Additionally, this review mapped the identified studies onto an engagement continuum framework to understand the current focus of PPE implementation in Sub-Saharan Africa, including how strategies have been applied to health system improvement.

\section{Traditional leadership support and collaboration}

Eight studies from six sub-Saharan African countries found traditional leadership support and collaboration was critical to effective PPE [28, 29, 42-44, 47, 50, 51]. However, the studies reported different forms and timings of traditional leadership support and engagement.

For instance, a study conducted in Ghana, reported that seeking early pathways to PPE by making decisions with traditional leaders, served to reassure community members that their cultural values were respected [43]. It also ensured engagement strategies were culturally sensitive as it reduced other social interruptions, which may affect the introduction of health interventions in the community [43, 47].

Studies found the use of traditional channels of communication (e.g. local dance, drama, and iconography) enhanced community engagement [29, 50, 51]. Additionally, using existing local traditional structures to implement health interventions [42, 44], and employing traditional systems (e.g. sub-chieftaincy structures) for post-implementation sustenance of health intervention programmes $[47,50,51]$, were central to effective implementation.

\section{Community advisory boards}

Community Advisory Boards (CABs; sometimes referred to as Community Health Committees, Community Advisory Groups, Community Workers Groups or Community Stakeholder Partnerships) were another strategy used to promote community health and develop peoplecentred health care systems across several Sub-Saharan African countries [28, 29, 31, 42]. CABs are informal advisory groups that seek community opinions or views from multiple stakeholders through focus groups, community meetings, interviews or suggestion boxes to promote people-centred health care services [29]. CABs usually included a range of representatives from the community and/or other health sector stakeholders [31]. In this review, seven articles reported findings from 10 Sub-Saharan African countries related to CAB [28, 29, $31,42,44,48,51]$. These included comprehensive processes for establishing CABs such as ensuring adequate representation from all minority groups in the community [31]. It was also found to be important to avoid underrepresentation or misrepresentation in CABs, by using transparent selection processes to avoid monopolisation of CABs by influential individuals $[28,51]$. Training and empowering $\mathrm{CAB}$ members to understand the health care system as well as the PPE programme were also important [28, 31]. Communication training was also critical to ensure programme objectives could be 


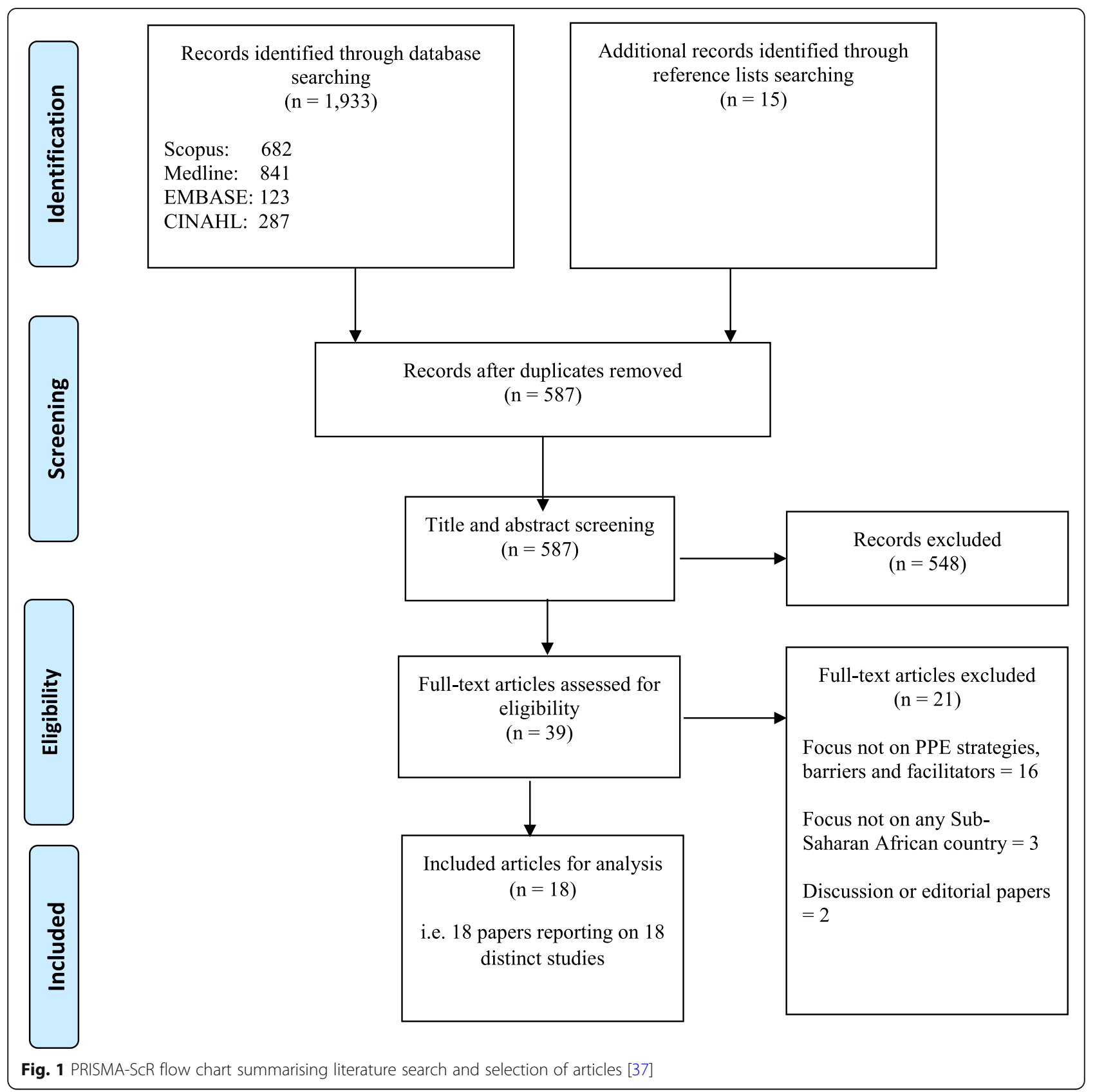

communicated to the community, and that feedback from the community was heard [28, 31].

Significantly, CABs helped develop trust and acceptance from local communities and offered an opportunity for communities to directly comment, critique and assist health professionals in developing people-centred health care services [31].

CABs as a PPE strategy have a number of advantages. They were found to be highly effective in urban towns where traditional leadership structures had less influence than in the villages and peri-urban areas [42]; served as a source for representing the voice of the community
[31]; helped ensure the aims of health programmes meet local needs of the community [42]; and communicated relevant health system information to the community [29]. Other benefits of CABs included monitoring health programme progress and providing regular updates [44, $48,51]$; promoting active community participation in new health interventions [42]; and ensuring the implementation of new community-based health interventions were sensitive to the values and practices of the community [31, 42].

A South African study found continuation of CABs, beyond the duration of a PPE implementation, was 
Table 1 Summary of publications on PPE strategies in Health System Improvement in SSA

\begin{tabular}{|c|c|c|c|c|c|c|c|}
\hline $\begin{array}{l}\text { Author (s) } \\
\text { and Year of } \\
\text { publication }\end{array}$ & $\begin{array}{l}\text { Country } \\
\text { of origin }\end{array}$ & Aims/Purpose & $\begin{array}{l}\text { Study Design and } \\
\text { Sample }\end{array}$ & $\begin{array}{l}\text { Intervention } \\
\text { setting }\end{array}$ & $\begin{array}{l}\text { Engagement } \\
\text { Strategies }\end{array}$ & Outcome (s) & Main finding (s) \\
\hline $\begin{array}{l}\text { Adongo et.al. } \\
\text { (2013) [46] }\end{array}$ & Ghana & $\begin{array}{l}\text { To assess the } \\
\text { impact of male } \\
\text { involvement in } \\
\text { Family Planning in } \\
\text { Northern Ghana }\end{array}$ & $\begin{array}{l}\text { Qualitative } \\
\text { descriptive design. } \\
90 \text { participants via } \\
12 \text { focus groups } \\
\text { discussions } \\
59 \text { In-depth } \\
\text { interviews }\end{array}$ & $\begin{array}{l}\text { Maternal } \\
\text { Health Services } \\
\text { (Family } \\
\text { Planning) }\end{array}$ & $\begin{array}{l}\text { Focus groups, } \\
\text { Community } \\
\text { educational } \\
\text { Workshops }\end{array}$ & $\begin{array}{l}\text { Spousal approval for } \\
\text { women in the use } \\
\text { of contraceptives; } \\
\text { CHPS effect on } \\
\text { male involvement } \\
\text { in Family Planning. }\end{array}$ & $\begin{array}{l}\text { Males were much } \\
\text { involved in family } \\
\text { planning activities } \\
\text { in communities } \\
\text { with functioning } \\
\text { CHPS compared to } \\
\text { those without } \\
\text { functioning CHPS. } \\
\text { Spousal approval } \\
\text { was still relevant for } \\
\text { women's use of } \\
\text { contraceptives. }\end{array}$ \\
\hline
\end{tabular}

\begin{tabular}{|c|c|c|c|}
\hline $\begin{array}{l}\text { Angwenyi } \\
\text { et.al., (2014) } \\
\text { [44] }\end{array}$ & Kenya & $\begin{array}{l}\text { To share } \\
\text { community } \\
\text { engagement } \\
\text { experiences in an } \\
\text { on-ongoing paedi- } \\
\text { atric malaria vaccine } \\
\text { trial conducted in } \\
\text { three study sites of } \\
\text { Kilifi County, Kenya. }\end{array}$ & $\begin{array}{l}\text { Mixed method } \\
\text { descriptive design } \\
25 \text { participants via } \\
\text { focus groups } \\
32 \text { participants via } \\
\text { in-depth interviews } \\
200 \text { through } \\
\text { observational } \\
\text { surveys }\end{array}$ \\
\hline
\end{tabular}

Baatiema Ghana et al., (2013) [28]

Campbell South et al., (2008) Africa [3] and evaluate the perspectives of the local stakeholders on their participation in the programme and its impact on health care delivery.

To report on the perceptions of the community on a 3-

Qualitative study

Malaria
Vaccine Trial

Interviews, Focus groups, Observation of Community Engagement activities

Kilifi County, Kenya.
Daily engagement with community stakeholders and the Trial teams' goals for community engagement before Malaria Vaccine trial

community
ces; CHPS
ion with
structures;
s CHPS with
unity interest.

Use of community resources; CHPS integration with pre-existing community structures; aligning CHPS with
community interest year programme that seeks to promote grassroots' responses to HIV/AIDS - mainly through rural health volunteers in KwaZuluNatal, South Africa. involving 12 participants via indepth interviews and 34 participants involved in 5 focus group discussions

\section{Primary Health Interviews, Care Focus groups Community Meetings}

17 participants via 17 participants group interviews

HIV/AIDS

Prevention Meeting with
community leaders

Compared with the trial teams' community engagement goals, regular engagement with community stakeholders had different expectations and goals. Engagement with community stakeholders was effective in reducing misconceptions about the vaccine trial, thereby contributing positively to a successful trial of the vaccine.

Engagement with community become sustained and more effective by acknowledging and using community resources and integrating CHPS with pre-existing community structures as well as aligning health interventions with community interest.

Increased grassroot support for volunteers in HIV/ AIDS home nursing care.

The project significantly enhanced community confidence in health volunteers and also contributed to increased community knowledge and acceptance for home nursing care for people living with HIV/AIDS.

\footnotetext{
Results highlighted that higher degrees 
Table 1 Summary of publications on PPE strategies in Health System Improvement in SSA (Continued)

\begin{tabular}{|c|c|c|c|c|c|c|c|}
\hline $\begin{array}{l}\text { Author (s) } \\
\text { and Year of } \\
\text { publication }\end{array}$ & $\begin{array}{l}\text { Country } \\
\text { of origin }\end{array}$ & Aims/Purpose & $\begin{array}{l}\text { Study Design and } \\
\text { Sample }\end{array}$ & $\begin{array}{l}\text { Intervention } \\
\text { setting }\end{array}$ & $\begin{array}{l}\text { Engagement } \\
\text { Strategies }\end{array}$ & Outcome (s) & Main finding (s) \\
\hline & $\begin{array}{l}\text { Ghana, } \\
\text { Nigeria, } \\
\text { Tanzania } \\
\text { \& Uganda }\end{array}$ & $\begin{array}{l}\text { and compare levels } \\
\text { of community } \\
\text { participation in the } \\
\text { Roll Back Malaria } \\
\text { programme in five } \\
\text { Sub-Saharan African } \\
\text { countries }\end{array}$ & $\begin{array}{l}\text { database using } \\
\text { Spider-gram theory } \\
\text { to assess } 503 \text { re- } \\
\text { ported malaria cases } \\
\text { across the studied } \\
\text { countries (excluding } \\
\text { Burkina Faso) }\end{array}$ & & $\begin{array}{l}\text { Back Malaria } \\
\text { Programme }\end{array}$ & $\begin{array}{l}\text { present at all levels } \\
\text { of the RBM } \\
\text { programme, } \\
\text { Varying degree of } \\
\text { community } \\
\text { participation existed } \\
\text { in the RBM } \\
\text { programme. }\end{array}$ & $\begin{array}{l}\text { of participation, } \\
\text { among other factors } \\
\text { resulted in } \\
\text { improved incidence } \\
\text { of malaria under the } \\
\text { Roll Back Malaria } \\
\text { programme }\end{array}$ \\
\hline $\begin{array}{l}\text { Dougherty } \\
\text { et al., (2018) } \\
\text { [52] }\end{array}$ & Ghana & $\begin{array}{l}\text { To examine how a } \\
\text { Community Benefit } \\
\text { Health }(\mathrm{CBH}) \\
\text { programme } \\
\text { influenced the } \\
\text { outcomes of } \\
\text { maternal health } \\
\text { services through } \\
\text { continuous } \\
\text { sustenance of } \\
\text { community-level } \\
\text { support among the } \\
\text { social networks of } \\
\text { women. }\end{array}$ & $\begin{array}{l}\text { Mixed method } \\
\text { study with } 1746 \\
\text { participants } \\
\text { involved in } \\
\text { questionnaire } \\
\text { survey and } 183 \\
\text { participants via in- } \\
\text { depth interviews \& } \\
\text { focus group } \\
\text { discussions }\end{array}$ & $\begin{array}{l}\text { Maternal } \\
\text { Health Services }\end{array}$ & $\begin{array}{l}\text { In-depth } \\
\text { interviews, } \\
\text { Focus groups, } \\
\text { Educational } \\
\text { meetings with } \\
\text { community } \\
\text { leaders }\end{array}$ & $\begin{array}{l}\text { Maternal health } \\
\text { behavioural } \\
\text { response to } \mathrm{CBH} \\
\text { interventions; Male } \\
\text { engagement in } \\
\text { maternal health. }\end{array}$ & $\begin{array}{l}\text { Results showed } \\
\text { improved maternal } \\
\text { health outcomes } \\
\text { such as antenatal/ } \\
\text { postpartum care, } \\
\text { birth attendance } \\
\text { and breastfeeding } \\
\text { following enhanced } \\
\text { engagement to } \\
\text { change community } \\
\text { and spousal } \\
\text { attitudes towards } \\
\text { maternal health } \\
\text { issues. }\end{array}$ \\
\hline $\begin{array}{l}\text { Gregson } \\
\text { et al., (2013) } \\
\text { [1] }\end{array}$ & Zimbabwe & $\begin{array}{l}\text { To investigate if PPE } \\
\text { or Community } \\
\text { grassroots } \\
\text { participation } \\
\text { resulted in } \\
\text { increasing HIV } \\
\text { Testing and } \\
\text { Counselling services } \\
\text { in Zimbabwe }\end{array}$ & $\begin{array}{l}\text { Prospective cohort } \\
\text { study involving } \\
5260 \text { participants } \\
\text { interviewed in } 2 \\
\text { consecutive rounds } \\
\text { of cohort survey }\end{array}$ & $\begin{array}{l}\text { HIV/AIDS } \\
\text { Prevention }\end{array}$ & $\begin{array}{l}\text { Interviews } \\
\text { Educational } \\
\text { programmes }\end{array}$ & $\begin{array}{l}\text { Uptake of HIV } \\
\text { Testing and } \\
\text { Counselling, } \\
\text { partnership with } \\
\text { organisations for } \\
\text { community support }\end{array}$ & $\begin{array}{l}\text { Results showed } \\
\text { increased HIV } \\
\text { testing and } \\
\text { Counselling uptake } \\
\text { services for } \\
\text { community } \\
\text { organisations due } \\
\text { to grassroot } \\
\text { participation } \\
\text { compared with } \\
\text { non-community } \\
\text { organisations }\end{array}$ \\
\hline $\begin{array}{l}\text { Kamanda } \\
\text { et al., (2013) } \\
{[47]}\end{array}$ & Kenya & $\begin{array}{l}\text { To describe the } \\
\text { approaches and } \\
\text { principles of } \\
\text { Community-Based } \\
\text { Participatory Re- } \\
\text { search through har- } \\
\text { nessing grassroots } \\
\text { power in conduct- } \\
\text { ing public health re- } \\
\text { search in Sub- } \\
\text { Saharan Africa. }\end{array}$ & $\begin{array}{l}\text { Randomised } \\
\text { Controlled Trial with } \\
\text { semi-annual assess- } \\
\text { ment of } 3130 \\
\text { participants }\end{array}$ & $\begin{array}{l}\text { Community } \\
\text { Public Health } \\
\text { Research }\end{array}$ & $\begin{array}{l}\text { Community } \\
\text { Advisory } \\
\text { Boards (CAB) } \\
\text { Household } \\
\text { interviews }\end{array}$ & $\begin{array}{l}\text { Adaption of } \\
\text { Community-Based } \\
\text { Participatory Re- } \\
\text { search in implemen- } \\
\text { tation of } \\
\text { community health } \\
\text { programmes and } \\
\text { public health } \\
\text { research } \\
\text { Cultural and } \\
\text { community } \\
\text { relevance in } \\
\text { shaping public } \\
\text { health research and } \\
\text { interventions }\end{array}$ & $\begin{array}{l}\text { Community } \\
\text { engagement } \\
\text { effectively shapes } \\
\text { public health } \\
\text { research design and } \\
\text { increases } \\
\text { community } \\
\text { participation in } \\
\text { subsequent } \\
\text { implementation of } \\
\text { community-based } \\
\text { health interventions }\end{array}$ \\
\hline $\begin{array}{l}\text { Mafuta et al., } \\
\text { (2015) [48] }\end{array}$ & Congo & $\begin{array}{l}\text { To explore how } \\
\text { health care } \\
\text { providers respond } \\
\text { to concerns of } \\
\text { women through an } \\
\text { existing social } \\
\text { accountability } \\
\text { mechanism in a } \\
\text { local setting. }\end{array}$ & $\begin{array}{l}\text { Exploratory study } \\
\text { involving two } \\
\text { health zones with } \\
48 \text { participants } \\
\text { interviewed }\end{array}$ & $\begin{array}{l}\text { Maternal } \\
\text { Health Services }\end{array}$ & $\begin{array}{l}\text { Interviews, } \\
\text { forming } \\
\text { Health } \\
\text { Committees } \\
\text { and CABs }\end{array}$ & $\begin{array}{l}\text { Varied perception of } \\
\text { health providers' } \\
\text { responsiveness, lack } \\
\text { of support for } \\
\text { women's } \\
\text { participation in } \\
\text { maternal health } \\
\text { despite existence of } \\
\text { many local } \\
\text { community health- } \\
\text { related groups }\end{array}$ & $\begin{array}{l}\text { Results showed } \\
\text { that, most women } \\
\text { did not have voice } \\
\text { to participate in } \\
\text { maternal health } \\
\text { issues. Among the } \\
\text { factors found } \\
\text { include; absence of } \\
\text { procedures to } \\
\text { express views, lack } \\
\text { of knowledge, fear } \\
\text { of reprisal, ethnicity, } \\
\text { power and status. }\end{array}$ \\
\hline Musesengwa & South & To document the & Qualitative case & Malaria and & Geospatial & Community & Results showed that \\
\hline
\end{tabular}


Table 1 Summary of publications on PPE strategies in Health System Improvement in SSA (Continued)

\begin{tabular}{|c|c|c|c|c|c|c|c|}
\hline $\begin{array}{l}\text { Author }(s) \\
\text { and Year of } \\
\text { publication }\end{array}$ & $\begin{array}{l}\text { Country } \\
\text { of origin }\end{array}$ & Aims/Purpose & $\begin{array}{l}\text { Study Design and } \\
\text { Sample }\end{array}$ & $\begin{array}{l}\text { Intervention } \\
\text { setting }\end{array}$ & $\begin{array}{l}\text { Engagement } \\
\text { Strategies }\end{array}$ & Outcome (s) & Main finding (s) \\
\hline $\begin{array}{l}\text { and } \\
\text { Chimbari, } \\
\text { (2017) [29] }\end{array}$ & $\begin{array}{l}\text { Africa \& } \\
\text { Zimbabwe }\end{array}$ & $\begin{array}{l}\text { experiences of } \\
\text { members in } \\
\text { Community } \\
\text { Engagement } \\
\text { processes during a } \\
\text { project } \\
\text { implementation in } \\
\text { two countries }\end{array}$ & $\begin{array}{l}\text { study approach } \\
\text { involving } 102 \\
\text { participants via } \\
\text { focus groups and } \\
66 \text { participants via } \\
\text { interviews }\end{array}$ & Bilharzia & $\begin{array}{l}\text { disease and } \\
\text { vector } \\
\text { Mapping, } \\
\text { Focus group, } \\
\text { Participatory } \\
\text { Rural appraisal } \\
\text { (PRAs) } \\
\text { workshops, } \\
\text { Biomedical } \\
\text { techniques, } \\
\text { CAB }\end{array}$ & $\begin{array}{l}\text { experience in } \\
\text { community } \\
\text { engagement } \\
\text { process, Research } \\
\text { naïve community in } \\
\text { public health } \\
\text { research and } \\
\text { implementation of } \\
\text { health programmes. }\end{array}$ & $\begin{array}{l}\text { continuously } \\
\text { soliciting views and } \\
\text { preferences from } \\
\text { main stakeholders } \\
\text { significantly } \\
\text { contributes to the } \\
\text { engagement } \\
\text { process. Also, } \\
\text { compared with } \\
\text { research } \\
\text { experienced } \\
\text { communities, } \\
\text { research naive } \\
\text { communities can } \\
\text { significantly } \\
\text { contribute to } \\
\text { research and } \\
\text { community } \\
\text { engagement } \\
\text { process }\end{array}$ \\
\hline $\begin{array}{l}\text { Ntshanga } \\
\text { et al., (2010) } \\
\text { [31] }\end{array}$ & $\begin{array}{l}\text { South } \\
\text { Africa }\end{array}$ & $\begin{array}{l}\text { To strengthen } \\
\text { community } \\
\text { mobilization, } \\
\text { awareness, } \\
\text { education and } \\
\text { involvement to } \\
\text { improve TB control } \\
\text { by building } \\
\text { community-health } \\
\text { sector partnership } \\
\text { through the estab- } \\
\text { lishment of Com- }\end{array}$ & $\begin{array}{l}\text { Cross sectional } \\
\text { study with a total of } \\
140 \text { participants } \\
\text { involved in } 2 \\
\text { Consultative } \\
\text { workshop }\end{array}$ & $\begin{array}{l}\text { Tuberculosis } \\
\text { Control and } \\
\text { Research }\end{array}$ & $\begin{array}{l}\text { Stakeholder } \\
\text { workshops } \\
\text { through CAB }\end{array}$ & $\begin{array}{l}\text { Mechanisms for } \\
\text { community } \\
\text { consultation and } \\
\text { participation }\end{array}$ & $\begin{array}{l}\text { Results revealed low } \\
\text { incidence of TB was } \\
\text { due to the regular } \\
\text { community } \\
\text { involvement in TB } \\
\text { control activities. } \\
\text { CABs were found to } \\
\text { be effective in } \\
\text { facilitating } \\
\text { community } \\
\text { involvement in } \\
\text { patient care. }\end{array}$ \\
\hline
\end{tabular}

Person et al., Tanzania To describe, using (2016) [49]

Riehman Kenya

et al., (2013)

[41] design communityowned structural and behavioural interventions to reduce the spread of Schistosomiasis.

To examine the impact of

Community-Based
Human-Centred De- study involving 5 sign in Community focus group co-designed process discussions with to prevent and con- community trol Schistosomiasis. figureheads, 35 It also aimed to ex- school-based displore how local cussions with chilknowledge, creativ- dren, 25 interviews ity and experiences with teachers and could be used to 16 parents

Organisations on community and individual level health outcomes; focusing on perceptions, awareness, knowledge, sexual risk behaviours of HIV/ AIDS.

\section{Schistosomiasis School-based education and training, focus groups, interviews \\ Sustainable PPE strategies for controlling Schistosomiasis; implementing PPE using Human- Centred design}

\begin{tabular}{|c|c|c|c|c|}
\hline $\begin{array}{l}\text { Quasi-experimental } \\
\text { cluster design with } \\
\text { multi-method data } \\
\text { collection involving } \\
4378 \text { adult } \\
\text { respondents }\end{array}$ & $\begin{array}{l}\text { HIV/AIDS } \\
\text { prevention }\end{array}$ & $\begin{array}{l}\text { Advocacy } \\
\text { workshops, } \\
\text { Community } \\
\text { meetings, } \\
\text { educational } \\
\text { workshops }\end{array}$ & $\begin{array}{l}\text { Higher levels of } \\
\text { Community-Based } \\
\text { Engagements, } \\
\text { PPE strategies for } \\
\text { Community-Based } \\
\text { Organisations in- } \\
\text { cluding sexual risk } \\
\text { behaviours, aware- } \\
\text { ness programmes, } \\
\text { and social trans- } \\
\text { formation (gender } \\
\text { ideology and social } \\
\text { capital). }\end{array}$ & $\begin{array}{l}\text { Study revealed } \\
\text { communities with } \\
\text { more Community- } \\
\text { Based Organisations } \\
\text { engage more and } \\
\text { therefore tend to } \\
\text { have less incidence } \\
\text { of HIV/AIDS com- } \\
\text { pared with those } \\
\text { with less } \\
\text { Community-Based } \\
\text { Organisations. }\end{array}$ \\
\hline
\end{tabular}

The outcome of the study revealed that community codesigned process with emphasis on Human-Centred Design principles of PPE ensures a more sustainable and effective interventions for controlling Schistosomiasis. 
Table 1 Summary of publications on PPE strategies in Health System Improvement in SSA (Continued)

\begin{tabular}{|c|c|c|c|}
\hline $\begin{array}{l}\text { Author (s) } \\
\text { and Year of } \\
\text { publication }\end{array}$ & $\begin{array}{l}\text { Country } \\
\text { of origin }\end{array}$ & Aims/Purpose & $\begin{array}{l}\text { Study Design and } \\
\text { Sample }\end{array}$ \\
\hline $\begin{array}{l}\text { Sakeah et al., } \\
\text { (2014) [50] }\end{array}$ & Ghana & $\begin{array}{l}\text { To examine the role } \\
\text { played by } \\
\text { community leaders } \\
\text { and residents } \\
\text { during the } \\
\text { implementation of } \\
\text { skilled delivery } \\
\text { programme and its } \\
\text { effect on improving } \\
\text { maternal health } \\
\text { care in a Ghanaian } \\
\text { community. }\end{array}$ & $\begin{array}{l}\text { Intrinsic case study } \\
\text { design with a } \\
\text { qualitative } \\
\text { methodology } \\
\text { involving } 29 \text { health } \\
\text { professional and } \\
\text { community } \\
\text { stakeholders } \\
\text { interviewed }\end{array}$ \\
\hline
\end{tabular}

\begin{tabular}{|c|c|c|}
\hline $\begin{array}{l}\text { Intervention } \\
\text { setting }\end{array}$ & $\begin{array}{l}\text { Engagement } \\
\text { Strategies }\end{array}$ & Outcome (s) \\
\hline $\begin{array}{l}\text { Maternal } \\
\text { Health Services }\end{array}$ & $\begin{array}{l}\text { Homes visits } \\
\text { through CHV, } \\
\mathrm{CHW} \text { and } \\
\text { interviews, } \\
\text { Traditional } \\
\text { authority } \\
\text { involvement }\end{array}$ & $\begin{array}{l}\text { Community } \\
\text { members role in } \\
\text { promoting skilled } \\
\text { delivery in CHPS } \\
\text { zones; mutual } \\
\text { collaboration and } \\
\text { engagement } \\
\text { between health } \\
\text { professionals and } \\
\text { community } \\
\text { members }\end{array}$ \\
\hline
\end{tabular}

Main finding (s)

community.

$\begin{array}{lll}\begin{array}{l}\text { Tancred } \\ \text { et al., (2017) }\end{array} & \text { Tanzania } & \text { To examine the } \\ \text { [53] } & \text { complexity of } \\ & \text { community-level } \\ & \text { quality improve- } \\ & \text { ment in health by } \\ & \text { building capacities } \\ & \text { of community } \\ & \text { members to use } \\ & \text { quality improve- } \\ & \text { ment behavioural } \\ & \text { change towards en- } \\ & \text { hancing maternal } \\ & \text { and newborn health } \\ & \text { in Tanzania. }\end{array}$

Tindana Ghana et al., (2011) [43]

Yeboah and
Jagri, (2016)

Ghana [51] practices frequently
Mixed method involving 83 participants interviewed or involved in focus groups, and quantitative data from secondary sources

Maternal and Newborn meetings with Health Volunteers, focus groups \& interviews

in Tanzania.

\section{To describe the} community engagement used during implementation of health projects or research through the Navrongo Health Research Centre of Ghana, and to identify the underlying cultural norms that informed those community entry practices

$\begin{array}{ll}\text { To identify the } & \text { Qualitative case } \\ \text { factors that } & \text { study design } \\ \text { constrain or } & \text { involving 103 } \\ \text { facilitate community } & \text { participants via } \\ \text { engagement } & \text { questionnaire } \\ \text { activities during the } & \text { survey, } \\ \text { implementation of } & 8 \text { participants via } \\ \text { the community- } & \text { interviews, } \\ \text { based Health Plan- } & \text { 1participant via } \\ \text { ning and Services } & \text { informal discussion. }\end{array}$

Qualitative case study design involving 116 participants in focus groups and 20 involved in in-depth interview

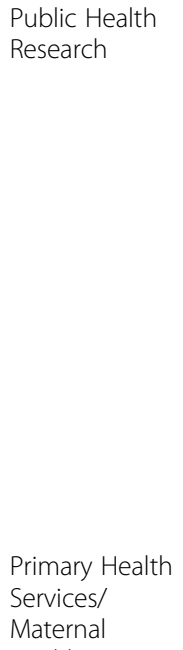

$\begin{array}{ll}\text { Health } & \text { Community } \\ \text { health durbar }\end{array}$

$\begin{array}{ll}\text { Health } & \text { Community } \\ \text { health durbar }\end{array}$

$\begin{array}{ll}\text { Health } & \text { Community } \\ \text { health durbar }\end{array}$

Community support during post implementation phase in a community-based health intervention; Assessing local community's commitment in participation on spidergram theory;

\author{
Study revealed \\ community \\ members are key to \\ promoting skilled \\ delivery and \\ reducing maternal \\ mortalities and \\ pregnancy related \\ complications. \\ Relationship \\ between \\ community Health \\ Volunteers and \\ Traditional Birth \\ Attendants were \\ found to be key in \\ providing health \\ education on skilled \\ and safe delivery.
}

The study results revealed facilitators of PPE as ones

which were most prevalent in highperforming communities, whilst the

barriers were those

which were lacking

in these highperforming communities. The identified facilitators and barriers are key to influencing behavioural change to improve maternal and newborn health

The study found that using existing traditional structures in a community reduces social disruptions during confidence in implementation of
health professionals, community-based and gender health interventions. inequities.

The study found
that having clearly
defined shared
leadership and
partnership role
between health
authorities and
communities prior
to implementing
community-based
health intervention


Table 1 Summary of publications on PPE strategies in Health System Improvement in SSA (Continued)

\begin{tabular}{|c|c|c|c|c|c|c|c|}
\hline $\begin{array}{l}\text { Author (s) } \\
\text { and Year of } \\
\text { publication }\end{array}$ & $\begin{array}{l}\text { Country } \\
\text { of origin }\end{array}$ & Aims/Purpose & $\begin{array}{l}\text { Study Design and } \\
\text { Sample }\end{array}$ & $\begin{array}{l}\text { Intervention } \\
\text { setting }\end{array}$ & $\begin{array}{l}\text { Engagement } \\
\text { Strategies }\end{array}$ & Outcome (s) & Main finding (s) \\
\hline & & $\begin{array}{l}\text { in the central region } \\
\text { of Ghana. }\end{array}$ & & & & $\begin{array}{l}\text { Establishing frame- } \\
\text { work to define } \\
\text { community role, ex- } \\
\text { pectations and re- } \\
\text { sponsibility prior to } \\
\text { implementing } \\
\text { community-based } \\
\text { health interventions. }\end{array}$ & $\begin{array}{l}\text { is key to reducing } \\
\text { post- } \\
\text { implementation } \\
\text { tensions and con- } \\
\text { flict that can disrupt } \\
\text { achieving the core } \\
\text { goals of the } \\
\text { programme. }\end{array}$ \\
\hline $\begin{array}{l}\text { Meiring et al., } \\
\text { (2019) [42] }\end{array}$ & Malawi & $\begin{array}{l}\text { To describe } \\
\text { community and } \\
\text { stakeholder } \\
\text { engagement } \\
\text { practices prior and } \\
\text { during a typhoid } \\
\text { conjugate vaccine } \\
\text { trial; drawing } \\
\text { lessons from the } \\
\text { challenges and its } \\
\text { impact on the } \\
\text { health outcomes. }\end{array}$ & $\begin{array}{l}\text { Qualitative research } \\
\text { design within a } \\
\text { Randomised } \\
\text { Controlled Trial with } \\
380 \text { participants } \\
\text { involved in Focus } \\
\text { groups, interviews, } \\
\text { other engagement } \\
\text { meetings }\end{array}$ & $\begin{array}{l}\text { Typhoid } \\
\text { Vaccine Trial }\end{array}$ & $\begin{array}{l}\text { Focus Group } \\
\text { Discussions, } \\
\text { School-based } \\
\text { meetings, } \\
\text { Community } \\
\text { Advisory Group } \\
\text { meeting and } \\
\text { Media } \\
\text { engagements }\end{array}$ & $\begin{array}{l}\text { Involving wide } \\
\text { range of } \\
\text { stakeholders; } \\
\text { starting community } \\
\text { engagement early } \\
\text { and throughout } \\
\text { implementation } \\
\text { phase; adequate } \\
\text { allocation of } \\
\text { resources to } \\
\text { support community } \\
\text { engagement; use of } \\
\text { broad range of } \\
\text { complimentary } \\
\text { engagement } \\
\text { activities. }\end{array}$ & $\begin{array}{l}\text { The study results } \\
\text { found there was } \\
\text { improved } \\
\text { awareness and high } \\
\text { turnout for the } \\
\text { vaccine trial } \\
\text { following an } \\
\text { enhanced } \\
\text { engagement with } \\
\text { local government } \\
\text { and community } \\
\text { leadership as well as } \\
\text { employing multiple } \\
\text { channels of } \\
\text { communication. }\end{array}$ \\
\hline
\end{tabular}

important [31]. For instance, as noted from the PPE experience in a typhoid conjugate vaccine trial in Malawi, among the key successes of the programme was its ability to empower and sustain the activities of the CAB beyond the vaccine trial phase, to continue providing regular updates from the community including reports on adverse drug reactions from the vaccine trial [42]. It was, therefore, recommended to avoid using CABs as an ad hoc PPE strategy for implementing community-based health programmes, but rather to sustain CABs to maintain links between the community and health care providers [31].

\section{Community education and sensitisation}

Evidence of using community education and sensitisation for PPE was reported in all 18 eligible studies - although different approaches were used. These include formal approaches such as health care institutions forming partnerships with community-based organisations (CBOs) [41]; community meetings, workshops and public durbars [1, 3, 28, 42, 44, 53]; training advertisements on radio, television and newspapers [31, 42, 52]; and other informal approaches such as presentations through drama [29]; wearing programme regalia (such as shirts, cups, flyers among others) [29, 42, 43]; and organising community sports and social events to promote health programmes $[29,43]$.

CBOs such as religious bodies, non-governmental organisations (NGOs) and other key community-based government agencies such as district and municipal assemblies [29, 31, 41], helped reduce the late presentation of cases to health facilities often attributed to spiritual causes [41]. Engagements with other key governmental organisations such as local assemblies and NGOs were also recommended to provide stronger collaboration to effectively engage communities, as well as influencing PPE policy direction, particularly, at the governmental level [31, 41].

The scoping review found community education and sensitisation programmes in Sub-Saharan Africa to have focused mainly on CABs or community representatives $[28,48]$; health volunteers/workers [3, 44, 51]; traditional rulers [43]; CBOs [41]; and health professionals [47, 48]. Community liaison officers have also been identified as an important group to include in the education and sensitisation programmes [29].

Community education strategies were noted to be effective particularly when targeted at specific audiences, or were directed towards achieving particular aims and objectives of a health programme [52]. Therefore, this PPE strategy was suggested to be aligned with the cultural practices maximising community cooperation [43].

\section{Community health volunteers}

Community health volunteers (CHVs), also known as community health workers have long been recognised to play a significant role in community participation. CHVs are lay health workers who voluntarily support the delivery of health care services at the community level by providing non-specialist basic health care services to 
communities, without receiving regular salary or a confirmed position within the health system [57]. The scope of their work usually includes health promotion, vaccination, bed-net distribution, prenatal care and basic nonclinical health support for people with chronic health diseases such as HIV/AIDS and tuberculosis [57-59].

CHVs have been involved in implementing community-based health programmes across many SubSaharan African countries [60]. Fourteen of the eighteen articles [3, 28, 29, 31, 41, 44, 46-48, 50-53] reported on CHVs role in PPE. CHVs have been found to be particularly important for rural and socioeconomically deprived communities in Sub-Saharan Africa [3, 46, 53].

CHVs have been used to improve the early diagnosis and treatment of malaria, diarrhoea, pneumonia among others by ensuring affected community members are referred promptly to health facilities for early treatment [3].

CHVs were found to easily gain the trust of the public and patients due to their close working relationships with communities $[28,41,44]$. Studies also reported that CHVs help ensure PPE information resonates with the cultural practices and health care services of the community $[3,31,46]$.

CHVs were found to be effective for both cost reduction and reducing community-related barriers to PPE initiatives [51, 53]. Therefore, CHVs have been recommended as key PPE approach to augment the shortage of professional health workers in SubSaharan Africa $[3,29,52]$.

In addition, a number of factors were identified to influence performance of CHVs. These include a range of contextual factors such as geographical access challenges $[3,28]$; socio-cultural norms $[47,52]$; financial constraints [51]; and functionality of the health system policy $[47,52]$. Thus, Dougherty et al. recommended the use of CHVs as a key component of any PPE approach that aims to change community behaviour (e.g. reducing resistance to the use of contraceptives) [52].

Various factors help account for the widely reported impact of CHVs in Sub-Saharan Africa, including the community-focused process of selecting CHVs [47], quality training given to CHVs [3], and adequate supervision $[3,50]$.

\section{Aligning and embedding PPE within pre-existing community structures}

Aligning PPE to pre-existing community structures has been found to be important for building community trust, as well as avoiding the duplication of PPE structures such as CABs or CHVs groups that may inadvertently end up competing with each other rather than working together towards a common goal [44]. Of the many PPE strategies, working within community structures has been used extensively in Sub-Saharan Africa [3, 28, 31, 43, 44, 47, 48, 51]. For instance, a randomised control of paediatric malaria vaccine trial in Kilifi, Kenya, integrated all pre-existing PPE decision making structures, including local assemblies, traditional authorities, CBOs and CHVs [44]. Another study indicated how working with pre-existing community structures for PPE was time-saving and cost effective compared to establishing new or parallel PPE structures [47].

In a study conducted in the Upper West region of Ghana, the success of a community-based health planning and services (CHPS) programme was largely attributed to the programme's ability to absorb all preexisting community structures such as the community unit committees, CHVs and traditional birth attendants. This to a large extent averted a possible confrontation or conflict between these existing community structures and the CHPS programme [28]. Other studies have also found this approach successful $[43,48,51]$. Although this strategy has been criticised for difficulties of implementation [31], it has been recommended as an effective PPE strategy during the introduction of new interventions such as vaccine trials or health programmes; particularly when programmes may result in community resistance or stigma (e.g. HIV/AIDS programmes) [3].

\section{Continuum and levels of patient-public engagement}

In addition to describing how PPE initiatives affected health and health system improvement in Sub-Saharan Africa, this paper also aimed to map PPE initiatives onto a framework comprising both health system levels and an engagement continuum. This provides an understanding of the current focus of PPE in Sub-Saharan Africa, particularly by situating the identified PPE

Table 2 Mapping identified papers to the Engagement Continuum and Service Levels Framework

\begin{tabular}{|c|c|c|c|}
\hline \multirow[t]{2}{*}{ Engagement Context } & \multicolumn{3}{|c|}{ Type of Engagement } \\
\hline & Consultation & Involvement & Partnership and Shared Leadership \\
\hline Research projects & $\begin{array}{l}{[1,41]} \\
(n=3)\end{array}$ & $\begin{array}{l}{[29,42-44]} \\
(n=3)\end{array}$ & $(n=0)$ \\
\hline Individual treatment & $(n=0)$ & $(n=0)$ & $(n=0)$ \\
\hline Service design & $\begin{array}{l}{[3,45]} \\
(n=2)\end{array}$ & $\begin{array}{l}{[28,31,46-53]} \\
(n=10)\end{array}$ & $(n=0)$ \\
\hline Macro policy/Strategic & $(n=0)$ & $(n=0)$ & $(n=0)$ \\
\hline
\end{tabular}


strategies within the context of health system improvement as recommended by others [15].

The continuum was adapted from Arnstein's ladder of citizen participation which contained eight rungs of engagement stages. In our paper, we have included three main stages: consultation, involvement and partnership/ shared leadership as previously applied by other scholars in different settings [12, 54-56]. The first stage on the continuum, 'consultation' has been described [12] as the weakest form of engagement providing patients/public with an opportunity to express their opinions/views, or as a means of disseminating information about the health care system. The 'involvement' stage, which is next on the engagement continuum, allows patients/ public to express their views and become involved in decision making process while not being part of the final decision-making process. The last stage on the continuum is 'partnership and shared leadership' which is generally characterised by shared power and responsibility among health professionals and public/patients working together as partners to design, manage and improve health care services [12].

Most studies identified in our scoping review $(n=13)$, were categorised as 'involvement' activities, whilst the remaining $(n=5)$ were categorised as 'consultation' (Table 2). None of the studies were categorised as 'partnership and shared leadership' activities. For instance, in the consultation category, Gregson et.al conducted a study in Zimbabwe to investigate if PPE resulted in increasing HIV testing [1]. This PPE approach was categorised as 'consultation' because members of the community were mainly educated about the importance of HIV testing. They were neither asked about their experiences nor what was important to them as major stakeholders in improving HIV testing [1]. Similarly, another study conducted in South Africa that investigated grassroot perceptions about interventions to support health volunteers was also categorised as 'consultation'. This was because the community ended up receiving information on how to support the health volunteer programme without any assurance of their experiences, concerns and suggestions being considered to improve the design and implementation of the health volunteer programme [3]. In Kilifi, Kenya, a study investigated community experiences during a malaria vaccine trial. There, the engagement moved from the 'involvement' category to 'consultation' over the course of the study [44]. This was because although the trial included feedback processes during the initial stages, this decreased overtime and the researchers reported that engagement had not worked as well as intended. The community ended up mainly receiving information intended to clarify misconceptions about the perceived negative effects of the vaccine, without necessarily being able to share their experiences, concerns or suggestions, or having their feedback contribute to improving the design of this community-based vaccine trial [44].

Overall, 13 studies were categorised as 'involvement'. Most involved feedback from the community or individuals to improve PPE strategies, but did not involve the public/patients in the final decision-making process. For instance, in a study assessing the impact of male involvement in family planning services in Northern Ghana, it was revealed that feedback and suggestions received from the community were mainly used to improve the PPE design [46].

However, the decision to respond (or not) to feedback was not in partnership with the community but was decided by the health care authorities. From the identified studies, none was categorised within the 'partnership and shared leadership' stage of the continuum.

Additionally, all identified studies were categorised according to the levels of the health system activity where the PPE initiatives were primarily located [61]. The three-tier categorisation comprised the individual person/patient treatment (e.g. individual patient attendance at health facilities, online patient portals or direct care of individual patients), service design (e.g improving overall service design or changing how the service responds to health interventions) and macro policy/strategic levels (e.g. national government PPE policies and strategies for improving overall health system). A fourth category included PPE activities occurring in the context of 'research projects' (e.g. PPE within community-based health research programmes or randomised clinical trials). All included studies $(n=18)$ investigated PPE either in the context of PPE within research projects $(n=6)$, or PPE at the 'service design' level $(n=12)$. None investigated engagement at the 'individual treatment' or 'macro policy/strategic' levels (Table 2).

\section{Discussion}

To the best of our knowledge, this scoping review is the first to systematically identify various PPE strategies implemented across Sub-Saharan Africa and map onto a framework of engagement to assess the current focus of PPE in Sub-Saharan Africa. Overall, our review identified five main PPE strategies implemented across SubSaharan Africa: (1) traditional leadership support and collaboration, (2) formation of CABs, (3) community education and sensitisation, (4) CHVs and (5) aligning and embedding PPE within pre-existing community structures. These PPE strategies were demonstrated in 10 Sub-Saharan African countries: Burkina Faso, Congo, Ghana, Kenya, Malawi, Nigeria, South Africa, Tanzania, Uganda and Zimbabwe.

Although a few previous reviews have reported on PPE strategies, these did not focus on PPE's role in health 
system improvement $[26,31,54]$. This review has examined PPE activities in the context of improving health systems. We found that traditional leadership support and CABs were the most widely used and effective PPE strategies across Sub-Saharan Africa. As found in previous studies, traditional leaders play important role in community development and are highly revered and regarded in Sub-Saharan Africa as custodians of traditions, values, culture, laws, religion and leaders also serve as reminders of pre-colonial sovereignty [43, 62-64]. Therefore, in most village communities, for instance, the traditional leadership system is more readily acknowledged by local people than formal governmental structures [65]. Thus, the findings of this review, as in past studies $[66,67]$ support seeking community entry approaches through traditional leaders to ensure PPE activities are endorsed, before communicating these activities to the wider community [43, 68-71].

While important, this strategy appears more in village and peri-urban communities rather than in urban cities where traditional leadership has a more limited role [42, 43]. In urban areas, CABs have been widely used as an effective alternative to traditional leadership for PPE. Advantages of CABs include helping to ensure PPE programmes are sensitive to the cultural needs of the people; meeting local needs; and ensuring proper communication of information to avoid misrepresentation.

Although traditional leadership and $C A B$ strategies have been widely used in Sub-Saharan Africa [72, 73], the present review also identified some key weaknesses. First, working through the traditional leadership structures can be expensive and time-consuming which can affect the timely implementation of PPE [43]. For instance, the local customary processes of visiting a chief and the cost of buying customary gifts, may slow PPE implementation. However, compared to the overall costs of PPE programme implementation, investing these time and costs early on in a new PPE activity are recommended. Further, CABs may not successfully reach all sectors of the community. For example, there may be cultural and language barriers among $C A B$ members and/or low levels of awareness of CABs in the communities $[28,42,44]$.

In contrast with past reviews $[2,12,15]$, our review focused on how identified PPE strategies were effectively implemented in different Sub-Saharan African health systems and communities. For instance, a systematic review of patient engagement in health priority setting identified CABs as an important PPE strategy without giving further details on how and when this strategy can be most effective [74]. All studies identified in our review were mapped onto a framework of engagement and health system levels to assess the current focus of PPE in Sub-Saharan Africa. The mapping also provides understanding of the levels and stages at which these PPE strategies have been implemented for health system improvement. Overall, most studies described engagement activities categorised as 'involvement'; with a few studies reporting PPE engagement categorised as 'consultation'. No PPE activities were categorised as 'partnership and shared leadership'. This accords with past reviews identifying PPE activities for health system improvement as 'tokenistic' rather 'genuine' participation $[12,55]$. Although other studies have argued against necessarily always aiming for the higher levels of engagement $[12,54]$, there is a need to try to move away from tokenistic approaches towards prioritising patient/community preferences, and moving to co-design for significant health service improvement $[12,13]$.

Additionally, PPE studies in Sub-Saharan Africa were all identified at either the 'service design' level of the health system or were focused on engagement with specific health research projects. None of the identified studies investigated PPE at the 'individual treatment' level or 'macro policy/strategic' level. This finding is, however, in contrast with past reviews that have mostly reported PPE at the 'individual treatment' level rather than the 'service design level' $[12,54]$. For instance, an international systematic review of patient engagement to improve health care quality found a large number of PPE studies at the 'individual treatment' level with only few located at the 'service design' level [54]. None of the identified 18 studies in our review had focused on PPE at all levels of the health system. For instance, in a study conducted in Malawi, a PPE programme directed towards improving community acceptance for a Typhoid Vaccine Trial, did not also consider individual patients' experiences with the health programme [42]. Similarly, a Ghanaian study investigated health system engagement with communities during the implementation of a CHPS programme without also focusing on individual patients' experiences [28]. However, as noted in previous studies, investigating PPE at all levels of the health system may provide a more effective understanding of PPE's overall effect on health system improvement $[56,75]$.

\section{Identification of gaps and recommendation for future research}

One key aim of scoping reviews is to identify gaps in knowledge which require further research [35]. Our review has identified several knowledge gaps. First, it was identified that most PPE studies in Sub-Saharan Africa have mainly focused on PPE in the areas of 'service design' or health research; mostly in advance of implementing new health interventions. While this is important, it is also crucial to have strong PPE activities across all levels of the health system including 'individual treatment' and 'macro policy/strategic' levels to provide 
a strong framework for implementation of health programmes and improvement $[56,75]$. Further primary research investigating PPE at all key levels of the health system is warranted.

In addition, our review findings also indicate the importance of future PPE initiatives in Sub-Saharan Africa utilising strategies found to work well; particularly, traditional leadership support and CABs.

\section{Limitations of the study}

Our review focused on only peer-reviewed articles; meaning some PPE studies reported in the grey literature will not have been included. Additionally, searching non-health sciences databases may have identified other relevant published articles. Also, despite the wide range of search terms used in different databases, this review may have missed some terms relevant to PPE in SubSaharan Africa. Because this review included only published English language articles, it may have missed some Sub-Saharan African PPE articles published in other languages. Lastly, our review focused on initiatives used when implementing PPE activities, the degree of engagement and levels of the health system. Further research is also required to understand the various barriers and facilitators of PPE in Sub-Saharan Africa. Further analysis of the identified papers in this scoping review is now underway to address this gap.

Despite the acknowledged limitations, a strength of this review is the focus on findings of direct relevance and importance to Sub-Saharan African countries and health systems. Further, the strategy used in this scoping review was comprehensive in reviewing public health and health sciences databases to identify PPE strategies for health system improvement in Sub-Saharan Africa.

\section{Conclusion}

Our review found that traditional leadership support and collaboration, formation of CABs, community education and sensitisation, $\mathrm{CHVs}$, and aligning and embedding PPE within pre-existing community structures were the main PPE strategies employed in Sub-Saharan Africa for health system improvement. The review also found traditional leadership support to be an effective and widely used PPE strategy in most village communities, whereas CABs were found to be effective in peri-urban and urban communities. We recommend future PPE initiatives in Sub-Saharan Africa consider these strategies and dedicate resources to fostering these important strategies in the early phases of PPE activity planning, design and implementation.

Again, although previous studies have reported some PPE strategies, these have not focused on PPE's role in health system improvement. Our review has identified and examined a key number of PPE strategies and their role in health system improvement, including analysing the health system levels and engagement continuum stages at which these strategies are functioning. PPE studies in Sub-Saharan Africa were mostly identified at the levels of 'service design' or health research. We therefore recommend future PPE studies focus on engagement across the range of health system levels to provide knowledge about the development of strong frameworks facilitating easy implementation of community-based health programmes throughout the sector.

Finally, for PPE to achieve enhanced opportunities for improving health systems, there is a need to move from more tokenistic approaches towards genuine participation. Hence, there is a need to prioritise patient and community preferences in the design and implementation of health interventions or programmes to achieve significant health system improvement in Sub-Saharan Africa.

\section{Abbreviations}

PPE: Patient-Public Engagement; LMICs: Low- and middle-income countries; CABs: Community Advisory Boards; CBOs: Community-based organisations; NGOs: Non-governmental organisations; CHVs: Community health volunteers; CHPS: Community-based health planning and services

\section{Acknowledgments}

We acknowledge the University of Otago Doctoral Scholarship granted to the first author to undertake a PhD degree programme.

\section{Authors' contributions}

SEA conceived the study under the supervision of SD and AF. SEA and CB developed and refined the search terms and conducted the search. SEA, EK and GG screened the material. SEA, AF and SD analysed the data with SEA preparing the first draft. AF and SD reviewed the first draft. SEA, AF and SD interpreted the results, revised the manuscript and all authors read and approved the submission.

Funding

Not applicable.

\section{Availability of data and materials}

All reviewed papers analysed during this study are included in this manuscript and the selected peer-reviewed studies are summarised in Table 1.

\section{Declarations}

Ethics approval and consent to participate

Conducting this systematic scoping review did not require approval from a research ethics committee.

\section{Consent for publication}

Not applicable.

\section{Competing interests}

All the authors declare no conflict of interest.

\section{Author details}

${ }^{1}$ Department of Preventive and Social Medicine, University of Otago, PO Box 56, Dunedin 9054, New Zealand. ${ }^{2}$ Center for Health Literacy and Rural Health Promotion, Accra, Ghana. ${ }^{3}$ Health Sciences Library, University of Otago,

Dunedin, New Zealand. ${ }^{4}$ Department of Health Administration and Education, University of Education, Winneba, Ghana. ${ }^{5}$ Department of General Practice and Rural Health, University of Otago, Dunedin, New Zealand. 
Received: 20 August 2021 Accepted: 24 September 2021 Published online: 05 October 2021

\section{References}

1. Gregson S, Nyamukapa CA, Sherr L, Mugurungi O, Campbell C. Grassroots community organizations' contribution to the scale-up of HIV testing and counselling services in Zimbabwe. AIDS. 2013;27(10):1657-66.

2. George AS, Mehra V, Scott K, Sriram V. Community participation in health systems research: a systematic review assessing the state of research, the nature of interventions involved and the features of engagement with communities. PLoS One. 2015;10(10):e0141091. https://doi.org/10.1371/ journal.pone.0141091.

3. Campbell C, Gibbs A, Maimane S, Nair Y. Hearing community voices: grassroots perceptions of an intervention to support health volunteers in South Africa. SAHARA J. 2008:5(4):162-77. https://doi.org/10.1080/172903 76.2008 .9724916

4. World Bank Group. The World Bank Annual Report 2012. Washington, DC: The World Bank Group; 2012.

5. World Health Organisation. Progress report on HIV, viral hepatitis and sexually transmitted infections 2019: accountability for the global health sector strategies, 2016-2021. Geneva: World Health Organization; 2019.

6. Hotez PJ, Kamath A. Neglected tropical diseases in sub-Saharan Africa: review of their prevalence, distribution, and disease burden. PLoS Negl Trop Dis. 2009:3(8). https://doi.org/10.1371/journal.pntd.0000412.

7. World Health Organisation: World health statistics 2019: monitoring health for the SDGs, sustainable development goals. 2019.

8. Alhassan RK, Nketiah-Amponsah E, Arhinful DK. Design and implementation of community engagement interventions towards healthcare quality improvement in Ghana: a methodological approach. Heal Econ Rev. 2016; 6(1). https://doi.org/10.1186/s13561-016-0128-0.

9. Potts $\mathrm{H}$, Hunt P. Participation and the right to the highest attainable standard of health; 2008

10. McCarron TL, Moffat K, Wilkinson G, Zelinsky S, Boyd JM, White D, et al. Understanding patient engagement in health system decision-making: a codesigned scoping review. Syst Rev. 2019;8(1):1-10. https://doi.org/10.1186/ s13643-019-0994-8.

11. Mitton C, Smith N, Peacock S, Evoy B, Abelson J. Public participation in health care priority setting: a scoping review. Health Policy. 2009;91(3):21928. https://doi.org/10.1016/j.healthpol.2009.01.005.

12. Gurung G, Richardson A, Wyeth E, Edmonds L, Derrett S. Child/youth, family and public engagement in paediatric services in high-income countries: a systematic scoping review. Health Expect. 2020;23(2):261-73. https://doi. org/10.1111/hex.13017.

13. Liang L, Cako A, Urquhart R, Straus SE, Wodchis WP, Baker GR, et al. Patient engagement in hospital health service planning and improvement: a scoping review. BMJ Open. 2018;8(1):e018263. https://doi.org/10.1136/ bmjopen-2017-018263.

14. Price A, Albarqouni L, Kirkpatrick J, Clarke M, Liew SM, Roberts N, et al. Patient and public involvement in the design of clinical trials: an overview of systematic reviews. J Eval Clin Pract. 2018;24(1):240-53. https://doi.org/1 0.1111/jep.12805.

15. Conklin A, Morris Z, Nolte E. What is the evidence base for public involvement in health-care policy?: results of a systematic scoping review. Health Expect. 2015;18(2):153-65. https://doi.org/10.1111/hex.12038.

16. British Medical Association: Patient and public involvement - a toolkit for doctors. 2011 Available at:[http://www.hqsc.govt.nz/assets/Consumer-Enga gement/Publications/DHB-guide/DG037-BMA-public-patient-informationtoolkit.pdf ] Last accessed on 21/09/2021.

17. Gurung G, Derrett S, Hill PC, Gauld R. Nepal's health facility operation and management committees: exploring community participation and influence in the dang district's primary care clinics. Primary Health Care Res Dev. 2018; 19(5):492-502. https://doi.org/10.1017/S1463423618000026.

18. Gurung G, Derrett S, Hill PC, Gauld R. The role of social audit as a social accountability mechanism for strengthening governance and service delivery in the primary health care setting of Nepal: a qualitative study. Crit Public Health. 2019;30(5):1-12. https://doi.org/10.1080/09581596.2019.16674 87.

19. Molyneux S, Atela M, Angwenyi V, Goodman C. Community accountability at peripheral health facilities: a review of the empirical literature and development of a conceptual framework. Health Policy Plan. 2012;27(7): 541-54. https://doi.org/10.1093/heapol/czr083.
20. Cleary SM, Molyneux S, Gilson L. Resources, attitudes and culture: an understanding of the factors that influence the functioning of accountability mechanisms in primary health care settings. BMC Health Serv Res. 2013;13(1):1-11. https://doi.org/10.1186/1472-6963-13-320.

21. Luxford K, Safran DG, Delbanco T. Promoting patient-centered care: a qualitative study of facilitators and barriers in healthcare organizations with a reputation for improving the patient experience. Int J Qual Health Care. 2011;23(5):510-5. https://doi.org/10.1093/intghc/mzr024.

22. Hall JJ, Taylor H. Health for all beyond 2000: the demise of the Alma-Ata declaration and primary health care in developing countries. Med J Aust. 2003;178(1):17-20. https://doi.org/10.5694/j.1326-5377.2003.tb05033.x.

23. Rifkin SB. Examining the links between community participation and health outcomes: a review of the literature. Health Policy Plan. 2014;29(suppl_2): ii98-ii106.

24. Alhassan RK, Nketiah-Amponsah E, Ayanore MA, Afaya A, Salia SM, Milipaak $J$, et al. Impact of a bottom-up community engagement intervention on maternal and child health services utilization in Ghana: a cluster randomised trial. BMC Public Health. 2019;19(1):791. https://doi.org/10.1186/s12889-0197180-8.

25. Horwood CM, Youngleson MS, Moses E, Stern AF, Barker PM. Using adapted quality-improvement approaches to strengthen community-based health systems and improve care in high HIV-burden sub-Saharan African countries. AIDS. 2015;29(Supplement 2):S155-64. https://doi.org/10.1097/QA D.0000000000000716.

26. Mash B, Ray S, Essuman A, Burgueño E. Community-orientated primary care: a scoping review of different models, and their effectiveness and feasibility in sub-Saharan Africa. BMJ Glob Health. 2019;4(Suppl 8):e001489. https://doi. org/10.1136/bmjgh-2019-001489.

27. Atinga RA, Agyepong IA, Esena RK. Willing but unable? Extending theory to investigate community capacity to participate in Ghana's community-based health planning and service implementation. Eval Program Plan. 2019;72: 170-8. https://doi.org/10.1016/j.evalprogplan.2018.10.001.

28. Baatiema L, Skovdal M, Rifkin S, Campbell C. Assessing participation in a community-based health planning and services programme in Ghana. BMC Health Serv Res. 2013;13(1):233. https://doi.org/10.1186/1472-6963-13-233.

29. Musesengwa R, Chimbari MJ. Experiences of community members and researchers on community engagement in an Ecohealth project in South Africa and Zimbabwe. BMC Med Ethics. 2017;18(1):76. https://doi.org/10.11 86/s12910-017-0236-3.

30. Atkinson J-A, Vallely A, Fitzgerald L, Whittaker M, Tanner M. The architecture and effect of participation: a systematic review of community participation for communicable disease control and elimination. Implications for malaria elimination. Malaria J. 2011;10(1):225.

31. Ntshanga SP, Ngcobo PS, Mabaso MLH. Establishment of a Community Advisory Board (CAB) for tuberculosis control and research in the Inanda, Ntuzuma and KwaMashu (INK) area of KwaZulu-Natal, South Africa. Health Policy. 2010;95(2-3):211-5.

32. Brear M, Hammarberg K, Fisher J. Community participation in research from resource-constrained countries: a scoping review. Health Promot Int. 2018; 33(4):723-33. https://doi.org/10.1093/heapro/dax010.

33. Ankomah SE, Fusheini A, Ballard C, Kumah E, Gurung G, Derrett S. Patientpublic engagement interventions for health system improvement in subSaharan Africa: a systematic scoping review protocol. Int J Health Plann Manag. 2020;36(2):273-81. https://doi.org/10.1002/hpm.3087.

34. Levac D, Colquhoun H, O'Brien KK. Scoping studies: advancing the methodology. Implement Sci. 2010;5(1):69. https://doi.org/10.1186/17485908-5-69.

35. Peters MD, Godfrey CM, Khalil H, Mclnerney P, Parker D, Soares CB. Guidance for conducting systematic scoping reviews. Int J Evid Based Healthc. 2015;13(3):141-6. https://doi.org/10.1097/XEB. 0000000000000050

36. Arksey H, O'Malley L. Scoping studies: towards a methodological framework. Int J Soc Res Methodol. 2005;8(1):19-32. https://doi.org/10.1080/1364557032 000119616.

37. Tricco AC, Lillie E, Zarin W, O'Brien KK, Colquhoun H, Levac D, et al. PRISMA extension for scoping reviews (PRISMA-SCR): checklist and explanation. Ann Intern Med. 2018;169(7):467-73. https://doi.org/10.7326/M18-0850.

38. Alhojailan MI. Thematic analysis: a critical review of its process and evaluation. West East J Soc Sci. 2012;1(1):39-47.

39. Braun V, Clarke V. Using thematic analysis in psychology. Qual Res Psychol. 2006;3(2):77-101. https://doi.org/10.1191/1478088706qp063oa. 
40. Froehlich JK, Hoegl M, Weiss M. Thematic thinking and individual performance in research and development. J Prod Innov Manag. 2015;32(6): 939-53. https://doi.org/10.1111/jpim.12210.

41. Riehman KS, Kakietek J, Manteuffel BA, Rodriguez-García R, Bonnel R, N'Jie $N D$, et al. Evaluating the effects of community-based organization engagement on HIV and AIDS-related risk behavior in Kenya. AIDS Care. 2013;25(sup1):S67-77.

42. Meiring JE, Sambakunsi R, Moyo E, Misiri T, Mwakiseghile F, Patel P, et al. Community engagement before initiation of typhoid conjugate vaccine trial in schools in two urban townships in Blantyre, Malawi: experience and lessons. Clin Infect Dis. 2019;68(Supplement_2):S146-53. https://doi.org/10.1 093/cid/ciy1110

43. Tindana PO, Rozmovits L, Boulanger RF, Bandewar SVS, Aborigo RA, Hodgson AVO, et al. Aligning community engagement with traditiona authority structures in global health research: a case study from northern Ghana. Am J Public Health. 2011;101(10):1857-67. https://doi.org/10.2105/A JPH.2011.300203.

44. Angwenyi V, Kamuya D, Mwachiro D, Kalama B, Marsh V, Njuguna P, et al. Complex realities: community engagement for a paediatric randomized controlled malaria vaccine trial in Kilifi, Kenya. Trials. 2014;15(1):65. https:// doi.org/10.1186/1745-6215-15-65.

45. Chilaka MA. Ascribing quantitative value to community participation: a case study of the roll Back malaria (RBM) initiative in five African countries. Public Health. 2005;119(11):987-94. https://doi.org/10.1016/j.puhe.2005.08.010.

46. Adongo PB, Tapsoba P, Phillips JF, Tabong PT-N, Stone A, Kuffour E, et al. The role of community-based health planning and services strategy in involving males in the provision of family planning services: a qualitative study in southern Ghana. Reprod Health. 2013;10(1):36-50. https://doi.org/1 0.1186/1742-4755-10-36.

47. Kamanda A, Embleton L, Ayuku D, Atwoli L, Gisore P, Ayaya S, et al. Harnessing the power of the grassroots to conduct public health research in sub-Saharan Africa: a case study from western Kenya in the adaptation of community-based participatory research (CBPR) approaches. BMC Public Health. 2013;13(1):91. https://doi.org/10.1186/14 71-2458-13-91.

48. Mafuta EM, Dieleman MA, Hogema LM, Khomba PN, Zioko FM, Kayembe PK, et al. Social accountability for maternal health services in Muanda and Bolenge Health Zones, Democratic Republic of Congo: A situation analysis. BMC Health Serv Res. 2015;15(1). https://doi.org/10.1186/s12913-015-1176-6.

49. Person B, Knopp S, Ali SM, A'Kadir FM, Khamis AN, Ali JN, et al. Community co-designed schistosomiasis control interventions for school-aged children in Zanzibar. J Biosoc Sci. 2016;48(Suppl 1):S56-73. https://doi.org/10.1017/ S0021932016000067.

50. Sakeah E, McCloskey L, Bernstein J, Yeboah-Antwi K, Mills S, Doctor HV. Is there any role for community involvement in the community-based health planning and services skilled delivery program in rural Ghana? BMC Health Serv Res. 2014;14(1):1-4.

51. Yeboah T, Jagri F. "We want financial accountability": deconstructing tensions of community participation in CHPS, Ghana. Dev Pract. 2016;26(6): 764-80. https://doi.org/10.1080/09614524.2016.1201048.

52. Dougherty L, Stammer E, Derbile E, Dery M, Yahaya W, Gle DB, et al. A mixed-methods evaluation of a community-based behavior change program to improve maternal health outcomes in the upper west region of Ghana. J Health Commun. 2018;23(1):80-90. https://doi.org/10.1080/1081073 0.2017 .1414901 .

53. Tancred T, Manzi F, Schellenberg J, Marchant T. Facilitators and barriers of community-level quality improvement for maternal and newborn health in Tanzania. Qual Health Res. 2017;27(5):738-49. https://doi.org/10.1177/104 9732316638831.

54. Bombard Y, Baker GR, Orlando E, Fancott C, Bhatia P, Casalino S, et al. Engaging patients to improve quality of care: a systematic review. Implement Sci. 2018;13(1):98. https://doi.org/10.1186/s13012018-0784-z.

55. Ocloo J, Matthews R. From tokenism to empowerment: progressing patient and public involvement in healthcare improvement. BMJ Qual Saf. 2016;25(8):626-32. https://doi.org/10.1136/bmjqs-2015-004 839.

56. Bate $\mathrm{P}$, Robert $\mathrm{G}$. Experience-based design: from redesigning the system around the patient to co-designing services with the patient. BMJ Qual Safe. 2006;15(5):307-10. https://doi.org/10.1136/qshc.2005.016527.
57. Woldie M, Feyissa GT, Admasu B, Hassen K, Mitchell K, Mayhew S, et al. Community health volunteers could help improve access to and use of essential health services by communities in LMICs: an umbrella review. Health Policy Plan. 2018;33(10):1128-43. https://doi.org/10.1093/heapol/ czy094.

58. Scott VK, Gottschalk LB, Wright KQ, Twose C, Bohren MA, Schmitt ME, et al. Community health workers' provision of family planning Services in low-and Middle-Income Countries: a systematic review of effectiveness. Stud Fam Plan. 2015;46(3):241-61. https://doi.org/10.1111/ j.1728-4465.2015.00028.x.

59. Aseyo RE, Mumma J, Scott K, Nelima D, Davis E, Baker KK, et al. Realities and experiences of community health volunteers as agents for behaviour change: evidence from an informal urban settlement in Kisumu, Kenya. Hum Resour Health. 2018;16(1):53. https://doi.org/10.1186/s12960-018-031 $8-4$.

60. Rifkin SB. Paradigms lost: toward a new understanding of community participation in health programmes. Acta Trop. 1996;61(2):79-92. https://doi. org/10.1016/0001-706X(95)00105-N.

61. Charles C, DeMaio S. Lay participation in health care decision making: a conceptual framework. J Health Polit Policy Law. 1993;18(4):881-904. https:// doi.org/10.1215/03616878-18-4-881.

62. Crothers C, Ntsebeza L, Thorton R, Biyela B, Sharma KC, Zips W, et al. Grassroots governance?: chiefs in Africa and the afro-Caribbean. Calgary: University of Calgary Press; 2003.

63. Kyed HM. Mutual Transformations of State and Traditional Authority. The renewed role of chiefs in policing and justice enforcement in Mozambique. Cadernos de Estudos Africanos. 2009;16(17):179-201.

64. Tshitangoni M, Francis J. Effectiveness of traditional leaders in engaging communities on development matters in Vhembe District of South Africa. J Hum Ecol. 2015;49(1-2):49-61. https://doi.org/10.1080/09709274.2015.11 906823

65. Logan C. The roots of resilience: exploring popular support for African traditional authorities. Afr Aff. 2013;112(448):353-76. https://doi.org/10.1 093/afraf/adt025.

66. Walsh A, Matthews A, Manda-Taylor L, Brugha R, Mwale D, Phiri T, et al. The role of the traditional leader in implementing maternal, newborn and child health policy in Malawi. Health Policy Plan. 2018;33(8):879-87. https://doi. org/10.1093/heapol/czy059.

67. Nyonator FK, Awoonor-Williams JK, Phillips JF, Jones TC, Miller RA. The Ghana community-based health planning and services initiative for scaling up service delivery innovation. Health Policy Plan. 2005;20(1):25-34. https:// doi.org/10.1093/heapol/czi003.

68. Tedrow VA, Zelaya CE, Kennedy CE, Morin SF, Khumalo-Sakutukwa G, Sweat $\mathrm{MD}$, et al. No "magic bullet": exploring community mobilization strategies used in a multi-site community based randomized controlled trial: project accept (HPTN 043). AIDS Behav. 2012;16(5):1217-26. https://doi.org/10.1007/ s10461-011-0009-9.

69. Okatch H, Andrae-Marobela K, Monyatsi KN, Masizana-Katongo A, Ngwenya BN, Muzila M. Perceptions of safety and efficacy of traditional medicines by community members in Botswana. Public Health. 2013;6(2):-157. https://doi. org/10.47556/J.IJFNPH.6.2.2013.3.

70. Ndekha A, Hansen EH, Mølgaard P, Woelk G, Furu P. Community participation as an interactive learning process: experiences from a schistosomiasis control project in Zimbabwe. Acta Trop. 2003;85(3):325-38. https://doi.org/10.1016/S0001-706X(02)00256-5.

71. Magoma M, Requejo J, Campbell OM, Cousens S, Filippi V. High ANC coverage and low skilled attendance in a rural Tanzanian district: a case for implementing a birth plan intervention. BMC Pregnancy Childbirth. 2010; 10(1):13. https://doi.org/10.1186/1471-2393-10-13.

72. Lwin KM, Cheah PY, Cheah PK, White NJ, Day NP, Nosten F, et al. Motivations and perceptions of community advisory boards in the ethics of medical research: the case of the Thai-Myanmar border. BMC Med Ethics. 2014;15(1):12. https://doi.org/10.1186/1472-6939-15-12.

73. Pratt B, Lwin KM, Zion D, Nosten F, Loff B, Cheah PY. Exploitation and community engagement: can community advisory boards successfully assume a role minimising exploitation in international research? Dev World Bioethics. 2015;15(1):18-26. https://doi.org/1 0.1111/dewb.12031.

74. Manafò E, Petermann L, Vandall-Walker V, Mason-Lai P. Patient and public engagement in priority setting: a systematic rapid review of the 
literature. PLoS One. 2018;13(3). https://doi.org/10.1371/journal.pone.0193 579.

75. Alderman KB, Hipgrave D, Jimenez-Soto E. Public engagement in health priority setting in low-and middle-income countries: current trends and considerations for policy. PLoS Med. 2013;10(8). https://doi.org/10.1371/ journal.pmed.1001495.

\section{Publisher's Note}

Springer Nature remains neutral with regard to jurisdictional claims in published maps and institutional affiliations.

\section{Ready to submit your research? Choose BMC and benefit from:}

- fast, convenient online submission

- thorough peer review by experienced researchers in your field

- rapid publication on acceptance

- support for research data, including large and complex data types

- gold Open Access which fosters wider collaboration and increased citations

- maximum visibility for your research: over $100 \mathrm{M}$ website views per year

At $\mathrm{BMC}$, research is always in progress. 